\title{
A REVIEW OF TAXATION REGULATORY DOCUMENTS ISSUED IN THE PERIOD OF JUNE-JULY 2014
}

\author{
L.Anisimova
}

The Main Trends of the Budget Policy for 2015 and the Planning Period of 2016 and 2017 deserves a particular emphasis in reviewing the above period. This is the first detailed analytical document concerning the current situation and development prospects of the Russian economy facing economic sanctions. The following short-run trends of Russia's economic policy are reflected in the document: the Russian Government intends to complete funding of a great deal of federal target programs, focusing efforts on those federal target programs which the Government considers relevant against sanctions aimed at increasing political and economic isolation of Russia, as well as due to the FIFA World Football Cup 2018 to be held in Russia; following a long period of financial stability, clear signs of impending problems caused by having to honor the obligations announced the Presidential Decrees issued in May 2014 have emerged against the backdrop of weakening financial potential, which results in reallocation of financial resources in the society for the benefit of the largest financial monopolies, namely banks established by the Russian Federation or the Central Bank of Russia (in particular, Vnesheconombank, Sberbank or Russia); the share of state debt as percentage of GDP is growing; financial support policies even more look like a hidden money issue; a few of the policies proposed in The Main Trends of the Budget Policy can be qualified as hidden and express hardening of the tax burden upon manufacturers and individuals in face of promises to keep the taxation rules intact until 2018; besides, wages of civil servants will see outstripping growth rates, which is quite a natural solution for an authoritarian mode of governance, with a view to ensuring loyalty and surveillance of government employees in a volatile economic environment ${ }^{1}$.

The main goal of the budget policy in 2015 and the planning period of 2016 and 2017 is to retain sustainability of the Russian budget system, as reflected in The Main Trends of the Budget Policy for 2015 and the Planning Period of 2016 and 2017. The transition to funding of federal target programs has greatly enhanced flexibility of budget planning. At the same time, the commitments assumed as part of the presidential election 2012 seriously restrict the potential of budget maneuvering to promptly response to political challenges arising out of the ongoing crisis in Ukraine and economic sanctions imposed on the Russian Federation. Experts understand that the current situation requires support of domestic manufacturers who have to replace and upgrade their outdated production facilities, the only solution that can help them to recover from the crisis - they have to change the production line, build up new manufacturing chains. In our opinion, the related risks should be mitigated, to the extent practicable, by establishing investment support funds which may attract private investment and public resources, in which case the latter can serve as kind of guarantee fund designed to repay private investment if a project is found to be inefficient or delayed. The

1 This solution appears to be wrong in practice, because it will unavoidably provoke displeasure among substantial social groups of Russia's population, undermine credibility in government authorities and may trigger social unrest in case of impairment of the living standards, wind-down of businesses. principle of interaction between the state and businesses during crisis may be as follows: businesses operate as "search entities" while the state as guarantor ${ }^{2}$. It is medium-sized businesses whose personnel are able to promptly and professionally evaluate core projects that are likely to become most efficient search entities. However, such entities will unlikely participate in large investment funds, because they are not going to share the profit from efficient projects with a great deal of other investors. The business mindset should be considered in establishing collective investment funds. Given the current recession period, the state should have the task to prevent private businesses from going bust, because if they find a promising project, the state will benefit from the project too and cover its losses by selling its interest in the project to other investors. However, The Main Trends of the Budget Policy provide for an alternative option of financial relations through reallocation of as much as possible resources from businesses and individuals to the state and state monopolies with a view to supporting financial and social stability in the society. Regretfully, this policy, even though it seems to be reasonable on the face of it, will further

2 For example, if the state and businesses collectively invest in a project which later appears to be inefficient, private entrepreneurs should have an opportunity to be promptly repaid at the cost of the "guarantee" share held by the state and go find a new project to invest in, because projects' investment cost is lowest during recession. 
accelerate stagnation: the policy is intended to provide support to the largest banks encumbered by liabilities and debts, defense enterprises, as well as secure consumption based on other than domestic production (i.e. it generates flawed consumers' demand which is met basically by import of items and products). In fact, real market manufacturers will eventually face a harder tax pressure instead of any financial aid, as provided for by The Main Trends of the Budget Policy.

All in all, it may be said that The Main Trends of the Budget Policy was developed by bureaucrats for the benefit of government agencies and state monopolies.

Let's have a closer look at the document.

The Main Trends of the Budget Policy has the following advantages. The document contains a detailed analysis of risks which can have an adverse effect on the scenario of the projected socio-economic development of the Russian Federation, which serves as the basis for the budget policy for the period between 2015 and 2017. The risks also include risks of tougher economic sanctions on Russia due to the crisis in Ukraine; risks determined by assets and liabilities which are currently not recognized in the balance sheet; risks of future costs relating to state guarantees, growth in liabilities of the constituent territories of the Russian Federation, etc.

In order to raise money for regional budgets, the document suggests to reduce the scope and list of benefits provided pursuant to the federal laws and regulations with respect to taxes and levies paid to the budget of the constituent territories of the Russian Federation and local budgets.

Indeed, the intention to retain the fiscal rule for the successive period deserves should be acclaimed. It is the fiscal rule that at the budget planning stage prevented unreasonable growth in government spending in the current year, thereby allowing financing of unbudgeted expenditures caused by the crisis in Ukraine and increased inflow of refugees to the Russian Federation. The Russian Government reasonably points to the fact that observance of the fiscal rule makes oil and gas revenues less significant in the budget revenues pattern, because no current fluctuations of prices of hydrocarbons are considered during budgeting.

The Russian Government is very careful in making efforts to resolve the issues of cutting expenditures: The Main Trends of the Budget Policy provides for incentives for later entitlement to work pension; specifies the requirements for a minimal pensionable service (extended from 5 to 15 years).

The documents contains positive initiatives, namely reassignment of administration of insurance contributions from extrabudgetary funds to the Federal Tax
Service of Russia (FTS of Russia) will be considered. In our opinion, together with the introduction of a universal formula for pension-benefit calculation this will at least halve the administrative staff management costs at state extrabudgetary funds.

At the same time, The Main Trends of the Budget Policy provides no solution for creating a revenue base in the regions. A possibility to authorize the constituent territories of the Russian Federation to have extra sources of financing is covered with an extreme caution: for example, "provisions establishing crediting of a series of non-tax revenues and levies" to their budget (perhaps, it first of all refers to penalties) is to be included into the Budget Code of the Russian Federation (BC of Russia), although it is only taxes that indeed can be local permanent sources of budget revenues.

In fact, the document suggests to increase tax pressure on manufacturers under the veil of coping with the dependence of budget of public extrabudgetary funds on federal budget transfers. For example, the document provides for gradual increase from January 1, 2015 of the base for the assessment of insurance contributions from $160 \%$ of the accrued average monthly nominal wages to $230 \%$.

A previous experiment in strengthening the tax burden on manufacturers by increasing contributions to public extrabudgetary funds already changed drastically (in 2010) the dynamics of progressive development of the Russian economy. If the state needs money for extrabudgetary funds, it shouldn't be done at the cost of manufacturers once again. It could be more reasonable to start with changing the source of financing of public social funds - it is wages of employees that should be the source. However, government officials still seem to believe that manufacturers' key task is to meet by all means the social commitments assumed on behalf of the state. This is not the case in a market-driven environment. If the state has no money to honor its commitments, it should disclaim a series of the commitments or restructure them (by making amendments to the respective legal acts), rather than devastate domestic manufacturers by forcing them, directly or indirectly, (by expanding the tax base) to have more mandatory expenses. Attempts to hide or "disguise" heavier tax burden on manufacturers are especially undesirable, because it would undermine businesses' credibility in government policies and makes them minimize their costs by withdrawing into "shadow", which will unavoidably lead to contraction of the state's revenue base and, consequently, trigger more sever social problems.

The envisaged policy of increasing civil servants' labor costs is very controversial. By 2017, the payroll is envisaged to raise by 2.48 times and the share of incentive 
payments in the payroll by $40 \%$. Labor costs of the staff employed at federal government bodies are planned to be financed on the basis of actual headcount, factoring in that financing of vacant positions is restricted to not more than $10 \%$ of the established headcount. Given that the said $10 \%$ seem to cover labor costs as well, the payroll will eventually grow by more than 2.7 times. There are plans to complete the transition to the "efficient contract" principles to be applied to every person employed in public (municipal) institutions (i.e. switch to a scheme of personal employment contacts with civil servants). In our opinion, this scheme is used to implement the intention to gradually withdraw from settlements with some public employees by granting them on preferable terms living quarters and country houses (dachas) via special funds and complete the transition to exclusively contractual relations. This intention (if contracts are limited in time and renewed on a competitive basis, specifying obligations which must constitute the subject matter of a contract) is indeed to be supported. However, growth rates in public sector remuneration show no reasonable economic substantiation: these are more than 10 times the accumulated rates of inflation (5-6\% annually) and growth rates of wages of employees engaged in education and science, medical services and culture in 2015-2017.

Facing economy's stagnation, restricted access to global markets and uncertainty over developments in the hydrocarbons market, the Russian Government have plans to increase substantially its financial borrowings, although repayment sources are nonobvious. The state debt will grow up to $15-20 \%$ of GDP in three years, against $10 \%$ recommended by the IMF. Furthermore, state debt servicing costs, according to the developers of The Main Trends of the Budget Policy, will be reduced, accounting for $10 \%$ or less of the total federal budget, in federal budget expenditures.

The Russian Government is now taking measures which can be qualified as hidden money issue. The largest Russian banks controlled by the state or the Central Bank of Russia appear to be the principal target of this policy.

Asserting an intention to increase returns of the management of the assets of the Reserve Fund and the National Wealth Fund (NWF) through higherreturn investment, the Russian Government has decided to invest in the NWF as deposits, up to $7 \%$ the $N W F$, in Vnesheconombank ${ }^{1}$, without being entitled to recall these deposits within a period of five years ${ }^{2}$,

1 Seven percent (7\%) of $\mathrm{Rb} 2,9$ trillion corresponds to $\mathrm{Rb} 200 \mathrm{bn}$ ( $\mathrm{Rb} 2,9$ trillion is planned by the FTS in 2015, see Table 5.19 The Main Trends of the Budget Policy).

2 See the Federal Law of July 21, 2014, No. 240 On the Amendments to Articles 3 and 19 of the Federal Law of and if the bank go busted, the deposits wouldn't be repaid unless all other creditors' claims are satisfied. In other words, if creditors demand bankruptcy of Vnesheconombank, the NWF's (state-owned fund) resources would be used to first of all repay to other creditors of Vnesheconombank. Besides Vnesheconombank, a substantial support has been given to Sberbank of Russia. For example, the Central Bank of Russia will issue unsecured loans to Sberbank, up to $\mathrm{Rb}$ 500bn until December 31, 2019 and/or for a period of 50 years at $6.5 \%$ p.a. (given the current market lending rates of up to $17 \%$ ) which may be rolled over for periods of 50 years without creditor's approval $^{3}$. In other words, an extra annual income of $\mathrm{Rb} 50 \mathrm{bn}$ has been guaranteed to Sberbank of Russia. To compare, Sberbank's profit before tax, according to IFRS financial statements, amounted to Rb $455 \mathrm{bn}$ in 2013 , i.e. the state has presented a gift of about $10 \%$ of annual profit to Sberbank of Russia ${ }^{4}$.

The financial situation in the Russian Federation may worsen by 2018. The Ministry of Economic Development (MED) anticipates that potential source of financing of the assumed liabilities will, inter alia, be the inflation tax-according to the MED's estimations, the ruble exchange rate would weaken to $\$ 38,8$ per ruble against the U.S. dollar in 2017. Therefore, household savings will depreciate, real labor costs in the market environment will decline (even now Russian manufacturers' products fail to be competitive at the current prices), while wages of civil servants will, as a reminder, be almost tripled ${ }^{5}$.

May 17, 2007 No. 82-FZ "On the Development Bank" and the Federal Law of July 21, 2014, No. 266-FZ "On the Amendments to Article 96.10 of the BC of Russia".

To compare: The Main Trends of the Budget Policy provides for contributions of budget resources - Rb 4,4bn in 2015, Rb 5bn in 2016, $\mathrm{Rb} 8,9 \mathrm{bn}$ in 2017 - to the Development Bank (Vnesheconombank (VEB)) for the introduction of a new repayment financing mechanism and support to Russian organizations undertaking investment projects which facilitate import substitution and enhancement of manufacturing of globally competitive products. The NWF's amounts of non-repayable contribution to be deposited at VEB ( $7 \%$ of the NWF) are, as can be seen, bigger by a factor of hundreds than the budget allocations intended to support Russian manufacturers undertaking investment projects on a repayable basis.

3 The Federal Law of July 21, 2014, No. 275-FZ On the Amendments to Articles 4 and 5 of the Federal Law "On Additional Measures in Support of the Financial System of the Russian Federation".

$410 \%$ of Rb $500 \mathrm{bn} \times 10 \%=(17 \%-6.5 \%)$. The data on the bank's profit before tax are available at www.sberbank.ru/moscow/ru/ investor_relations/accountability/sberbank_in_numbers/

5 To compare: wages of other categories of employees will be raised by $14.5 \%$ in three years (in accordance with The Main Trends of the Budget Policy, wages of other categories of workers employed at educational, culture, healthcare, and social service institutions will be indexed on the basis of a projected inflation, namely by $5.0 \%$ in $2015,4.5 \%$ in $2016,4.3 \%$ in 2017 ). 
Thus, despite all the statements made at the highest level, the policy of increasing maintenance costs of the state machinery, providing large-scale support to state-run and close-to-the-state largest financial corporations (banks) still remains in force through reallocation of resources in favor of government agencies and pubic financial monopolies, build-up of the state debt (borrowings draw away resources from the free market, thereby further weakening the investment potential of domestic manufacturers), rather than through economic development.

According to The Main Trends of the Budget Policy, federal budget revenues are planned to reach $\mathrm{Rb}$ 16,6 trillion in 2017 (against Rb 14,2 trillion in 2014). The revenue pattern, as envisioned by the developers of The Main Trends of the Budget Policy, will change in favor of other than oil and gas revenues ${ }^{1}$.

Revenues are projected taking account of amendments to the fiscal, budget, customs laws and regulations issued by the Russian Government. Following listed are some of the proposed amendments.

A) To generate federal budget revenues, the Russian Government has plans to introduce an excise on export of natural gas by Gazprom OAO via the Blue Stream gas pipeline to Turkey. The Main Trends of the Budget Policy envisages that the introduction of the said excise will generate extra revenues to the federal budget, $\mathrm{Rb} 41,7 \mathrm{bn}$ in 2015, Rb 38,9bn in 2016 and $\mathrm{Rb}$ 38,9bn in 2017. This proposal of the Russian Government needs refinement.

The Agreement between the Russian Federation and Turkey stipulates that in the period until December 31, 2015 Gazprom OAO will pay an excise of $\$ 2$ per $1000 \mathrm{~m}^{3}$ of natural gas at a cost of up to $\$ 65$ per1000 $\mathrm{m}^{3}$ and $30 \%$ of a price higher than $\$ 65$. Excises on natural gas export supplies have been abolished in the Russian Federation since 1.04.2004, although the terms of the Agreement with Turkey were left unchanged, but Gazprom OAO was exempted from the excise under the provisions of the internal Russian legislation. The same Agreement with Turkey exempted Gazprom OAO from export customs duties. At the same time, the Russian Government's Regulation of 30.08.2014 No. 754 provides for a customs duty on export of natural gas, $30 \%$ of its customs value. Legal grounds for restoring Gazprom's obligation to pay the excise are unclear: a special excise has been introduced on Gazprom OAO and the Blue Stream? However, the Tax Code of Russia prohibits introduction of special customs treatments. Will the terms of the Agreement with Turkey be applied? However, the Agreement provides

1 The current ratio of federal budget revenues is 1:1.12 in favor of oil and gas revenues, the ratio is expected to change in 2017 to 1:1.14 in favor of other than oil and gas revenues. for payment of the excise until December 31, 2015 and, if the Agreement is applied, Gazprom OAO is automatically exempted from export customs duty, thereby causing loss to budget revenues ${ }^{2}$. Therefore, by applying the terms of the Agreement with Turkey, the Russian Government establishes a preferential tax treatment for Gazprom OAO, retaining the excise instead of customs duties. Any extra revenues to the Russian budget is therefore unlikely to be expected.

B) Given that the rates of the charge for the use of federally owned bodies of water, and water tax rates haven't been indexed since 2004, the Russian Government suggests that these should be indexed beginning with 2015 (by an average of 1.28, 1.63, 2.08 against the current rates, beginning with January 1, 2015, 2016, 2017 respectively). Individuals will face an insignificant increased in utility tariffs on water supply and sewerage, because the water tax accounts for $1.3-1.5 \%$ of energy enterprises' costs of sales, according to the estimates of the Russian Government. By increasing the water tax, extra federal budget revenues will amount to $\mathrm{Rb} 2,8 \mathrm{bn}$ in 2015, $\mathrm{Rb} 7,2 \mathrm{bn}$ in 2016, Rb 12,9bn in 2017.

C) The rates of the charge for the use of forests are expected to be indexed on the basis of deflator indices which consider an inflation rate. The rates of the charge for the use of forests haven't been indexed since 2009. Extra revenues to the federal budget may amount to about $\mathrm{Rb} 0,8 \mathrm{bn}$ annually.

D) Bank of Russia's share of profit credited to the federal budget under a standard of 50 to $75 \%$ (the standard is provisional for the time being) is to be increased on a constant basis. As a result, extra federal budget revenues will amount to about $\mathrm{Rb} 27,0 \mathrm{bn}$ annually in 2016-2017, according to the estimates of the Russian Government.

E) The Russian Government's proposal to prohibit to claim deduction of VAT amounts paid at the cost of the federal budget to suppliers and contractors for capital construction and fixed assets, will allow the budget to simultaneously "fulfill" the two tasks as follows: generate extra budget revenues ${ }^{3}$ and at the same time report on increase in the amounts of allocated financing and subsidies on education, scientific activities, the development of medical services and culture (the subsidies will obviously include VAT costs). According

2 In 2013, $1000 \mathrm{~m} 3$ of natural gas was priced a bit less than \$US350. The customs duty on export of $1000 \mathrm{~m} 3$ will amount to \$US105, and the introduction of an excise under the Agreement with Turkey will generate \$US85,5 \{(350 - 65) x 30\%\} of budget revenues.

3 Save up to $18 \%$ of the amounts, approved by the Federal Law On the Federal Budget for the successive financial year, of budget allocations and subsidies appropriated to the recipients - by repayment to the budget of VAT paid under agreements. 
to the estimates of the Russian Government, these extra "revenues" will amount to Rb 15,6bn in 2015, Rb 13,4bn in 2016, Rb 13,6bn in 2017.

F) Also, the state duty rates will be indexed on the basis of an accrued inflation index (inflation in Russia will stay at 61\% between 2009 and 2015, according to the estimates of the Russian Government). As a result, federal budget revenues will increase by another $\mathrm{Rb} 17,5 b n$ in 2015, Rb 17,3bn in 2016, Rb 16,9bn in 2017.

G) A proposal to open personal accounts with Federal Treasury agencies to keep records of federal budget allocations as contribution to the authorized capital and charter funds of legal entities, as subsidies to legal entities is indeed a good one in general. This will increase free liquidity to cover cash gaps occurring during the federal budget execution. It remains unclear how budget revenues were calculated - perhaps, it refers to saving of resources due to discontinued fundraising for these purposes. According to the estimates of the Russian Government, extra Rb 20,0bn in 2015, Rb 40,0bn annually in 2016-2017 will be generated (perhaps, saved).

$H$ ) Drastic growth in excises on expensive cigarettes is expected within the next three years, whereas no excise burden will be be imposed on regular types of cigarettes to prevent increase in counterfeit tobacco products. Extra budget revenues from the raised excise on cigarettes, according to the Russian Government, would amount to $\mathrm{Rb} 16,6 \mathrm{bn}$ in 2015, $\mathrm{Rb} 16,6 \mathrm{bn}$ in 2016, Rb 96,2bn in 2017.

I) To prevent abuses such as evasion of customs duties when natural persons purchase goods from foreign suppliers via the Internet, it is expected to introduce a cost standard (150 euros) for duty-free import of goods and a tonnage rating (10 kg of imported goods for personal use) for duty-free import of goods delivered by a carrier to the address of a natural person, as well as delivered via international mail services to the address of an addressee as natural person. Extra revenues from the customs duty on e-trade will amount to about Rb 20bn annually.

J) To provide financing of "Socio-Economic Development of the Crimea Federal District until 2020" federal target programs, the Russian Government plans to sell in an open market a share of OAO Rosneft stocks held by Rosneftegaz OAO. Extra budget revenues are estimated Rb 100,0bn in 2015.

K) In 2015, the consolidated budget of the constituent territories of the Russian Federation is expected run a deficit of $\mathrm{Rb} 942,3 \mathrm{bn}$ with a decline to $\mathrm{Rb} 905,9 b n$ by 2017 . To cope with the deficit, the Russian Government suggests that the regions should be entitled to introduce a sales tax at a rate of up to
$3 \%$. This policy, according to the Ministry of Finance of Russia, will allow the budget of the constituent territories of the Russian Federation to generate their own revenues, increasing consolidated budget revenues of the constituent territories of the Russian Federation by $\mathrm{Rb} 194,8 b n$ in 2015, Rb 210,7bn in 2016, Rb 230,0bn in 2017. It should be noted that the Constitutional Court of the Russian Federation (CC of Russia) recognized the sales tax as contradicting the Constitution of the Russian Federation with regard to taxation of selfemployed entrepreneurs using a simplified taxation system, accounting and reporting, thereby making it impractical ${ }^{1}$.

In our opinion, The Main Trends of the Budget Policy for 2015-2017 will have to be refined. The fact that the budget is facing an extremely tangled situation is determined by the adoption of the Federal Law of July 21, 2014 No. 214-FZ which suspends until January 1, 2015 the provisions of the Budget Code of the Russian Federation (BC of Russia) establishing the procedure for adoption of the Federal Laws On Amendments to the "Federal Law on Taxes and Levies", federal laws, resulting in changes to budgets' revenues in the budget system of the Russian Federation. According to the $\mathrm{BC}$ of Russia, these laws should have been adopted under federal laws - no later than one month prior to the date of submission to the State Duma of a draft law on the federal budget for the successive fiscal year and the planning period, concerning regional and local taxes - prior to submission of the draft law on the budget of a constituent territory of the Russian Federation (local government body) for the for the successive fiscal year ${ }^{2}$.

The following legal acts among those adopted during the period under review are worth of mentioning.

1. The Russian Federation adopted Federal Law of 28.06.2014 No. 173-FZ On the Specifics of Conducting Financial Operations with Foreign Nationals and Legal Entities, Amendments to the Code of Administrative Offences of the Russian Federation (CAO of Russia), and Annulment of Certain Provisions of Legal Acts of the Russian Federation. The said Federal Law establishes the procedure according to which Russian banks and financial institutions provide foreign tax authorities with data on accounts and transactions of the residents of these foreign states. Additionally, the Federal Law establishes that Russian entities operating in the financial market may provide a foreign tax authority

1 The Ruling of the Constitutional Court of the Russian Federation of June 19, 2003 No. 11-P.

2 The Budget Code of the Russian Federation, Paragraph 2, Article 53, Paragraph 2, Article 59, Paragraph 2, Article 64, Paragraph 2 Article 174.1 
and/or foreign fiscal agents authorized by a foreign tax authority to withhold foreign taxes and levies (hereinafter referred to as "foreign tax authority") with information subject to the consent of the customer as foreign taxpayer to provide the information to the foreign tax authority.

Since the Central Bank's Instruction of 7.07.2014 No. 3312-U, registered with the Ministry of Justice of the Russian Federation July 8, 2014 No. 33103, explains the procedure for termination of agreements on the provision of financial services with foreign customers, as well as closing of bank accounts on grounds arising from the specifics of a foreign state's laws and regulations on taxation of foreign accounts, it may be said that the Russian Federation has created a mechanism enabling banks and financial companies to interact with tax authorities in other states with regard to preventing tax evasions by residents of these states. In our opinion, this issue has been settled in time.

2. Federal Law of 28.06.2014 No. 188-FZ makes amendments to certain legal acts of the Russian Federation on mandatory social security.

There are few curiosities too. The amounts paid as severance benefit and average monthly wages during the period of employment with regard to an amount that is "three times the overall size of average monthly wages or six times the size of average monthly wages for workers dismissed from organizations situated in the regions of the Extreme North and equivalent areas" have been excluded from the amounts to be paid as insurance contributions. Given that the substance of the amended clause is exempt all types of compensatory payments from insurance contributions (pursuant to the standards established under the laws and regulations of the Russian Federation), the amendment literally provides for a benefit as exemption from insurance contributions with regard to payments beyond the established standards. This implies that an organization whose former CEO (Deputy CEO, chief accountant) was paid a very high severance will not have to pay insurance contributions neither within nor beyond the established limits (wages over 3 or 6 months). This seems to be unreasonable when the Pension Fund of Russia (PF of Russia) is facing deficit, especially given the abolition of the previously granted social benefits covering contributions paid to cover travel expenses and luggage transportation costs to the vacation area of employees and their family members employed and residing in the regions of the Extreme North. This benefit has been abolished with regard to covering family members' travel expenses.

The same Federal Law introduces employers' obligation to pay insurance contributions subject to the existence of labor relations with foreign nationals and stateless persons sojourning in the Russian Federation, regardless of the existence and effective period of labor contracts within a year ${ }^{1}$.

Considering that upon the transition to insurance contributions many previous regulatory provisions of the Tax Code of Russia for the purposes of the unified social tax (UST) have ceased to be applied to insurance contributions, these mechanisms are being legally reconstructed with regard to every single insurance contribution severally. In fact, this is duplication of the provisions set forth in the Tax Code of Russia on granting delays (deferred payment) in payment of insurance contributions, penalties and fines, relations with banks as to provision of information on payers' account balances. Since the adopted standards contain economically ill-substantiated differences from the similar procedures established for payment of taxes under the Tax Code of Russia, in our opinion, the work of accountants of taxpayers as payers of insurance contributions will be unreasonably complicated.

3. Federal Law of 21.07.2014 No. 244-FZ refines the rules of patenting self-employed entrepreneurs. In particular, lower limits on the size of income eligible for granting a patent have been removed. Only a ceiling of $\mathrm{Rb} 1 \mathrm{~m}$ or less has been established. In addition, the upper limit on income is subject to indexing adjusted for inflation by a deflator coefficient over a corresponding calendar year.

4. Federal Law of 21.07.2014 No. 238-FZ makes amendments to the Tax Code of Russia, extending the scope of persons obliged to keep records for the purpose of value added tax (VAT), using invoices. In particular, the Federal Law establishes that in case of issuing and/or receiving invoices by persons (including those who are exempted from VAT) doing business for the benefit of other person under commission agreements, agency agreements which stipulate sale and/or purchase of goods (works, services), ownership rights on behalf of the commissioner (agent) or under freight forwarding agreements, as well as in performing real estate developer functions, these persons (commissioners) become liable for keeping records of received and issued invoices with regard to the given type of activity carried out as representative of this other person.

Such commissioners are obliged to provide the tax authorities at the place of registration with the record log of duly received and issued invoices on or before the $20^{\text {th }}$ date of the month following the elapsed tax period.

5. Federal Law of 23.06.2014 No. 167-FZ establishes the procedure for taxation of the personal income tax

1 The benefit was previously granted to the extent that the term of a labor contract with a foreign national or stateless person was six months or less within a calendar year. 
(PIT) and the tax on incomes generated by legal entities and individuals from transactions with securities of restructured non-state pension funds (NSPFs). The amounts of contributions of NSPFs themselves, as well as contributions of the PF of Russia to the pension accruals guarantee fund have been allocated to operational costs. In other words, these amounts reduce the NSPFs profit tax base, the same way as banks' contributions to the deposit insurance system.

6. Federal Law of 28.06.2014 No. 198-FZ introduces technical changes to the text of the Tax Code of the Russian Federation with regard to reorganization of the judiciary system and delegation of powers of the Supreme Commercial Court (SCC) to the Supreme Court of the Russian Federation. The same Federal Law establishes the state duty payment procedure and refines the size of certain types of state duty. State duty rates will be further revised pursuant to the Federal Law of 21.07.2014 No. 221-FZ, which, given the inflation indices in 2009-2014, has raised $50-60 \%$ the state duty rates on a wide range of services, in particular when pecuniary claims, petitions for divorce are filed, etc. The state duty rates are expected to be further refined (see The Main Trends of the Budget Policy for 2015-2017).
The same Federal Law introduces new types of state duty, including licensing of notarial activities (Rb 100,000) and multi dwelling unit management business ( $\mathrm{Rb} 30,000$ ), a decreasing coefficient 0.7 to the size of state duties paid by individuals has been introduced, in case of using the Unified Portal for Public and Municipal Services, regional and other web portals.

7. Federal Law of July 21, 2014 No. 249-FZ makes amendments to the BC of Russia on the distribution of certain types of state duty between regional budgets and the federal budget.

In particular, the state duty on federal executive bodies' legally significant actions in case of filing a request and/or documents required for the execution thereof to the multi-purpose center for the provision of public and municipal services will be credited to the federal budget and regional budgets at 50\%. The same standards of state duty distribution among budgets have been established for actions of authorized agencies of the constituent territories of the Russian Federation related to licensing of the multi dwelling unit management business. 